\title{
Special Section in Memoriam: Xiaojia Ge, 1954-2009
}

\author{
Irving I. Gottesman · Sheng He $\cdot$ Leslie D. Leve \\ Jenae M. Neiderhiser
}

Published online: 14 February 2010

(C) Springer Science+Business Media, LLC 2010

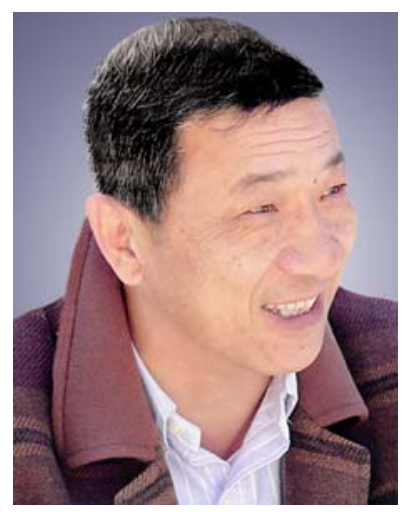

Not long before his recent untimely death at age 55 from cancer, Xiaojia Ge, a Professor in the Institute of Child Development at the University of Minnesota, edited a special issue of Acta Psychologica Sinica that would introduce behavioral genetics in depth to a Chinese audience of scientist-scholars. He commissioned nine articles from his colleagues in the U.S.A., U.K., Sweden, and Finland, research that sampled normal and abnormal behaviors and contemporary behavioral genetic methodologies. We (Irving I. Gottesman, Sheng He, Leslie D. Leve, and Jenae M. Neiderhiser) facilitated a selection of three of

I. I. Gottesman $(\varangle) \cdot$ S. He

University of Minnesota, Minneapolis, MN, USA

e-mail: Gotte003@UMN.edu

\section{D. Leve}

Oregon Social Learning Center, Eugene, OR, USA

J. M. Neiderhiser

The Pennsylvania State University, University Park, PA, USA

those pieces, and negotiated with John Hewitt, Editor of Behavior Genetics, to reproduce them here in a Special Section as a memorial to the good offices of Xiaojia Ge as the major ambassador between Chinese and American hopes for internationalization and future collaborations in our field of interest. All nine papers can be accessed at http://journal.psych.ac.cn/xuebao/en/dqml.asp for the October, 2008 issue.

Xiaojia Ge was born in Beijing on October 24, 1954. He was the third of three children in his sibship. At the time of his birth his father, Yaochang Ge, was a clerk working for the Chinese Customs Service; his mother, Zhengjing Chen, was a teacher at a local junior high school. In 1960, as a result of political persecution, his family was forced to move to a remote rural County, Kaili, in Guizhou Province in southern China. There, Xiaojia Ge had only 6 years of grade school education. The Great Cultural Revolution in China came in 1966, decimating Chinese culture, intellectual and family life, and science. For the next few years, Xiaojia's education was curtailed, and at times he took up long-distance running and soccer in a local sports school for youth and on a provincial soccer team. In 1970, to help ease the hardship suffered by his family, he took a job as a coal miner at the Tongzi Coal Mine in Guizhou. He returned 3 years later from the coalmine and took a job as a machinist in an agricultural equipment factory.

His life took a turn for the better in 1977 when China restored the College Entrance Examination for the first time since the beginning of the Cultural Revolution. In a very short time Xiaojia Ge prepared for the entrance exam and made up much of the missing high school course work on his own. With high scores Xiaojia entered Sichuan University to study history. In 1982 he earned a Bachelor of Arts degree in Chinese History and World History. He entered Xiamen University to study Transportation and 
Economy in Taiwan in the Institute of Taiwan Studies. In 1984 he earned a Master of Science in Sociology. He continued working in the Institute afterward. In 1986 he was recruited by Professor Shumin Huang of Iowa State University to study sociology for a doctoral degree, and by 1990 he had earned his Ph.D. in Sociology from Iowa State University.

From 1990 to 1995 Xiaojia conducted research at the Center for Family Research of Iowa State University as a research associate. It was while he was at the Center for Family Research that Xiaojia began his work focused on gene-environment interplay, authoring a paper that would become widely recognized and replicated by at least two other research teams. From 1995 to 2006 he was employed as a faculty member in the Department of Human Development at the University of California at Davis, where he rose through the ranks and became a Full Professor. In 2006 he moved to the University of Minnesota, Twin Cities to serve as a senior professor in the Institute of Child Development. He was an exceptional scholar and a dedicated educator. His research focused on child and adolescent development in various contexts, including interactions between biological and genetic factors and social contexts, and the long-term consequences of adolescent emotional and behavioral problems. He is best known for his multidisciplinary approach to mining large data sets and for his seminal findings on the effects of pubertal timing on adolescent developmental outcomes. The National Council for Family Research recognized Professor Ge for his outstanding article combining theory and research, entitled "The Developmental Interface between Nature and Nurture: A Mutual Influence Model of Child Antisocial Behavior and Parent Behavior", published in Developmental Psychology. In his all too short academic life he mentored 10 graduate students and postdoctoral associates, with eight of them presently serving as professors at various universities.

One of the many lasting aspects of Xiaojia Ge's legacy is the Early Growth and Development Study (EGDS), a prospective adoption study designed to advance our understanding of how genes and environments work together to influence child development. In many ways the EGDS was a natural extension of Xiaojia's 1996 Developmental Psychology paper focused on gene-environment interplay. Xiaojia Ge's ever-present wit, sharp eye for methodological flaws, and good humored patience as a collaborator were essential, not only for getting the project off the ground and funded but for its continuing progress.

Since 2004 Xiaojia served as an invited foreign editor for the Chinese Journal of Psychology published by the Chinese Academy of Sciences, and as an Adjunct Professor of Psychology in the Institute of Psychology, Academy of Sciences in Beijing. The Institute will now name the laboratory and Twin Register he founded in Beijing after him, as the Ge Xiaojia Adolescent Development and Behavioral Genetics Laboratory. He worked tirelessly to help train a new generation of scientists, both in America and China, in modern integrated developmental psychology, through direct mentoring, exchange visits, and publishing research articles in the Chinese Journal of Psychology and other Chinese journals. One of his dream projects cut short by his untimely departure was to build a world renowned center for developmental psychology and behavioral genetics research at the Institute of Psychology, Academy of Sciences. Ge had already taken the initiative to start a school age twin register in Beijing; at present it already has enrolled more than 1,000 twin pairs. The Beijing twin register will continue into the future, and serve as part of Xiaojia's legacy to Chinese and American behavioral genetic research.

Xiaojia was a loving husband and a dear friend to his wife, and a caring father and a great mentor to his son. He was always an active member of the community wherever his life's journey took him. He was loyal and giving to friends. He also stood up for principles and truth without pretense. His knowledge was well rounded and often spiced with a comedian's sense of humor. His refreshing candor, his patented style of slow-rolling speech and his quiet smile will live on in the memories of his family, friends, and colleagues.

In May of 2009 he was diagnosed with an advanced stage lung cancer. On August 26, 2009, he succumbed to the cancer and passed away peacefully at the University of Minnesota Masonic Cancer Center at 4:40 PM. He is survived by his mother Zhengjing Chen, wife Ronghua (Jenny) Li, bother Zhaoguang Ge, sister Xiaoyu Ge, and son Yije Ge. Louis Pasteur commented to the effect that, science knows no nation-Xiaojia Ge's legacy to ChineseAmerican behavioral science provides a brilliant exemplar of that sentiment.

\section{Selected Bibliography}

Chen Z, Guo F, Yang X, Li X, Duan Q, Zhang J, Ge X (2009) Emotional and behavioral effects of romantic relationships in Chinese adolescents. J Youth Adolesc 38:1282-1293

Ge X, Lorenz FO, Conger RD, Elder GH Jr, Simons RL (1994) Trajectories of stressful life events and depressive symptoms during adolescence. Dev Psychol 30(4):467-483

Ge X, Best KM, Conger RD, Simons RL (1996a) Parenting behaviors and the occurrence and co-occurrence of adolescent depressive symptoms and conduct problems. Dev Psychol 32(4):717-731

Ge X, Conger RD, Cadoret RJ, Neiderhiser JM, Yates W, Troughton E (1996b) The developmental interface between nature and nurture: a mutual influence model of child antisocial behavior and parent behaviors. Dev Psychol 32(4):574-589 
Ge X, Conger RD, Elder GH Jr (1996c) Coming of age too early: pubertal influences on girls' vulnerability to psychological distress. Child Dev 67(6):3386-3400

Ge X, Conger RD, Elder GH (2001) Pubertal transition, stressful life events, and the emergence of gender differences in adolescent depressive symptoms. Dev Psychol 37(3):404-417

Jin R, Ge X, Brody GH, Simons RL, Cutrona CE, Gibbon FX (2008) Antecedents and consequences of psychiatric disorders in African-American adolescents. J Youth Adolesc 37:493-505
Leve LD, Harold GT, Ge X, Neiderhiser JM, Shaw D, Scaramella LV, Reiss D (2009) Structured parenting of toddlers at high versus low genetic risk: two pathways to child problems. J Am Acad Child Adolesc Psychiatry 48(11):1102-1109

Natsuaki MN, Ge X, Wenk E (2008) Continuity and changes in the developmental trajectories of criminal career: examining the roles of timing of first arrest and high school graduation. J Youth Adolesc 37:431-444 